\section{CSR EMAT Is an Opportunity for Responsible Decision-Making}

\author{
Nora Rodek Berkes \\ University of Pannonia, Hungary \\ rodek.nora@uni-pen.hu
}

\begin{abstract}
Corporate social responsibility is an expected behaviour in Western countries, but the approach still does not have a clear interpretation in Hungary. As a result of the increasing prestige of the CSR approach, socially responsible thinking and action also are expected from the companies operating in Hungary. Company executives carry out CSR activities in many cases - but not consciously. The objective of this research therefore was the development of a guidance and evaluation criteria that can support managers in responsible decision-making and applying the CSR approach to a strategic level. On the other hand, this management tool allows the measurement of CSR excellence in companies; therefore, they become comparable in their CSR performance, which offers opportunities for further research. The study presents the development of CSR EMAT and the results achieved through the measurements.
\end{abstract}

Keywords: corporate social responsibility, EFQM excellence model, CSR EMAT, CSR excellence management, assessment tool

\section{Introduction}

Corporate social responsibility has a several decades' old history. One of the first definitions of CSR came from Howard Bowen who refers to the obligations of businessmen to make those decisions that are desirable in terms of the objectives and values of our society (Bowen, 1953). People began to deal with the CSR approach to the modern sense since the early 1950s in the United States and other developed countries. We hear more and more about sustainable development, ethical corporate governance, ecological footprint, and similar concepts, which are inspiring us to behave and operate responsibly - from individuals to large enterprises. In today's globalized world, there is often a blurring of geographical boundaries in business; therefore, corporate executives must keep pace with the parent companies and partners' expectations as well as with the needs of the market and society (Braun-Line, 2007). Beyond profit making, companies must respond to environmental and social challenges in order to maintain competitiveness (Braun, 2013). In our country, however, this effort is still unfolding; one reason for this is that there is no available guideline or interpretation in Hungarian for company managers. On the other hand, the approach originally launched from the US and Western cultures, carrying the particularities of the certain culture, which are not always interpretable in the Hungarian practice. The Hungarian research results confirmed that the development of a CSR guideline and supporting tool are needed (Szlávik, 2009, p. 160).
ORIGINAL SCIENTIFIC PAPER

RECEIVED: NOVEMBER 2016

REVISED: MARCH 2017

ACCEPTED: APRIL 2017

DOI: 10.1515/ngoe-2017-0017

UDK: 005.35:005.53

JEL: M14

Citation: Rodek Berkes, N. (2017).

CSR EMAT Is an Opportunity for

Responsible Decision-Making. Naše gospodarstvo/Our Economy, 63(3), 37-46. DOI: 10.1515/ngoe-2017-0017 
According to Lepoutre and Heene, the leaders of small- and medium-sized enterprises have professional qualifications rather than management knowledge; since they are typically focused on the daily operation, there is not enough time for strategic development (Lepoutre \& Heene, 2006). We have MBA training at University of Pannonia, where we ask students in each year about their CSR activities. This is a management training course in four different towns in Hungary. Our personal experience has highlighted the fact that most of the company executives are not aware of the concept of CSR, and they identify CSR as environmental protection and charity. The CSR concept has, however, many more elements. We cannot expect managers to be able to decide responsibly without knowing this information. In many cases, when we started introducing the elements of the CSR concept and their practical implementation, the managers realized that they carry out many similar activities in their own company - but not in a conscious way. Universities have major responsibilities in knowledge transfer; they should inform their students and the companies operating in their environment about the new management approaches and tools (Birkner-Máhr, 2016). To find a solution for this problem, we aimed to develop a quality management system and guideline to help managers understand the CSR approach. This guideline can contribute to the application of the CSR approach at a strategic level as well.

The research questions are as follows: 1) Can the EFQM excellence model serve as the base for a CSR excellence management tool and guideline?; 2) Can this management tool help managers to assess their company?

The first step in the research was to find the right excellence model and then to collect its content. While developing this management system, we found it important to keep the CSR framework, but tailoring it according to the corporate operating conditions in Hungary, functioning as a guideline for the management-level application. A further importance of the research is that the approach has no universally accepted measuring system (Venturelli et al., 2017). The methods used by Western countries to measure CSR activities are not always applicable in the Hungarian corporate practice. Following the literary background of the CSR approach, the CSR excellence model and the assessment criteria will be presented with the results obtained during the evaluation.

\section{Literature Review}

Corporate social responsibility is an important means of achieving sustainability (Berkes et al., 2015). Sustainable development meets the needs of the present, without compromising the needs of the future generations
(Brundtland, 1987). Although the conscious and environmentally aware decisions promoting sustainability refer to the future, they need to be taken into consideration in the present (Laszlo, 2008). Since changing opinions and attitudes is a slow process, it is expedient in the case of present decisions to take into account the circumstances with the support of appropriate management techniques in order to enhance effectiveness. Responsible managers should think of social efficiency as an evaluation criterion of their own management processes (Maak-Pless, 2006). How much social welfare is created? Are the employees satisfied with the working conditions? Are they motivated well? Are they growing as human beings in their work, or are they exploited so that they present a lost social capital? Performance for a responsible manager is defined as a combination of social, environmental, and economic performances (Laasch, 2015). Waddock and Bodwell have coined the term "total responsibility management" (TRM) to describe a framework that translates total quality management tools and practices to the field of responsible management (Waddock-Bodwell, 2007). If we take the definition of sustainability into consideration, we can see that the two concepts are related and complementary. CSR means the activities of a company that support the society while relating to legal standards and the direct interests of the company (Broomhill, 2007). Sustainable development meets the needs and expectations of humanity without threatening the future generation (Crowther-Martinez, 2004). The responsible operation has a number of results that support sustainability and thereby the long-term competitiveness as well (Benn, 2011).

The implementation of the corporate social responsibility concept is affected by the people who make up the organization. The key element of CSR-oriented management is the leadership itself and its commitment, habit, ethical compliance, disposition, and socialization experience (LaashConaway, 2013). The social commitment of the company to the practical aspects of CSR: 1) Unifying the CSR orientation of the management; 2) the development and operation of reporting and measurement systems; 3) the continuous improvement of the quality of work; 4) social and eco-labels, the purposeful and conscious use of product marks; 5) implementing socially responsible investments (Kun, 2004).

Table 1 summarizes the results of the responsible operation. The stakeholders' loyalty and motivation are among the results of the utmost importance, which also is a prerequisite for competitiveness (Harrison-Wicks, 2013). Beyond the positive results of responsible operations, CSR also can be a solution for the challenges of generational change. Currently, the labour market is represented by three generations who differ not only in their characteristics but in their working relationship and their needs about the working conditions 
Table 1. Results of Responsible Operation

\section{Results of Responsible Operation}

- the company profit will grow; it will be easier to obtain corporate resources as the company will be more attractive to investors

- it improves the company's reputation and image

- the loyalty and motivation will rise among the stakeholders, especially the consumers and staff, which reduces internal monitoring and coordination costs

- improves the competitive position of the company, increases the market share - niche markets also can be reached

- cost savings can be achieved (environmental investments), the company will be attacked less by the NGOs, the media, and other stakeholders: risk management

- reduces the risk of tightening legislation

- transaction costs will be reduced because of the relationship and trust

- as the governments and international organizations consider CSR as a more important question, the company can obtain subsidies easier through its responsible behavior

- CSR can be a tool of stakeholder relationship management

- it develops proactivity

- it provides opportunities for innovation (e.g., SRI, responsible investment products, or environmentally friendly products)

Source: Author's research data (2015)

are very different as well (Adelina, 2007). The next generation of employees typically is characterized as having much more environmentally conscious thinking, and the Z-Generation is also called the "Responsible Generation." Therefore, in the future, companies will need to place greater emphasis on the challenges arising from human resource management that fit the needs of future generations (Tari, 2011). There are many aspects that prove that it is necessary for company executives to be familiar with the CSR concept and to apply it on the management level.

CSR has several definitions as a result of growing interest in the topic from companies, governments, and the general public (Blowfield-Murray, 2008). Matten and Moon have highlighted the heterogeneous nature of the various definitions (Matten-Moon, 2008). The numerous definitions of CSR that have emerged are well summarized in a work by Dahlsrud (2008). We have chosen some definitions, which in our opinion the best summarize the essence of the approach. According to the World Business Council for Sustainable Development, the definition of CSR is as follows: commitment of business to contribute to sustainable economic development, with the employees, their families, local community, and society cooperating in order to improve the quality of life (WBCSD, 2000). CSR is regarded as a set of tools that improves working conditions beyond legal requirements and is favourable for the society (Vogel, 2006). Many companies are focusing on corporate social responsibility issues, but, unfortunately, most companies are still based on self-interest and make CSR as part of their economic calculation, which is the opposite of altruistic ethical behaviour (Holliday, 2002). The main points of CSR concepts are that, after mapping, who their stakeholders are; thus, the company has to incorporate these CSR values and interests into their business operation while maintaining their profitability. Socially responsible behavior radiates confidence toward both employees and consumers (Frank, 2004). Many companies, however, see that a few donations and environmental measures are enough for responsible behavior, but for sustainable development a long-term strategy is needed. ISO (2010) offers the following definition for CSR: "The awareness of an organization/area for the impacts of its decisions on society and environment through transparent and ethical behavior that contributes to sustainable development, it takes into account the expectations of stakeholders, it is in compliance with international norms of behavior and integrated throughout the organization.”

Corporate social responsibility concentrates not only on environmental issues but also on communication and employee care, so applying this concept can be a great tool in order to build trust and raise employee satisfaction and motivation. Employee satisfaction and motivation can even influence the success of an organisational project. Based on Kaszás et al.'s study, it is evident that the external motivation of the project manager is definitely an important influencing success factor with regard to time (Kaszás et al., 2016: 17-18; NémethPéter, 2016). The essence of CSR activity is communication, including an internal and external relationship with stakeholders. The stakeholders' views and ideas are becoming increasingly important, so the bidirectional communication is essential (Boutilier, 2009). There are many positive effects of CSR that can be observed in case of companies. 


\section{Research Framework and Method}

Our research was motivated by the idea to develop a guideline of CSR, which enables companies to learn about the concept and its elements, so this information could help them in responsible decision-making. The research focused on the following two hypotheses.

H1: The EFQM excellence model can serve as the base for a CSR excellence management tool and guideline.

H2: CSR EMAT can help managers to assess their company; therefore, they will be comparable in their CSR performance.

The research was structured as follows: 1) Collect the elements of international standards and directives for social responsibility and sustainability; 2) Find a quality management system whose framework is appropriate to develop the CSR excellence model; 3) Develop the CSR excellence management and assessment tool (CSR EMAT) based on the logic of the EFQM excellence model; 4) Validate the model at the companies; 5) Use the improved and validated assessment tool at the companies and compare the results.

In order to develop the CSR EMAT model, the first step was to collect the elements of international standards and directives for social responsibility and sustainability.
Table 2 demonstrates the international CSR guidelines and standards and their core subjects. Since the early 1990s, the European Commission has taken an active interest in corporate social responsibility. In 2001, this interest manifested itself in the form of a green paper (or consultation document) entitled "Promoting a European framework for corporate social responsibility." This 35-page document sets out the principles underlying CSR and introduces some of the sustainability tools at the disposal of companies and governments (EC, 2001). The UN Global Compact is a call to companies everywhere to 1) voluntarily align their operations and strategies with ten universally accepted principles in the areas of human rights, labour, environment, and anti-corruption and 2) take actions in support of UN goals, including the millennium development goals (UN Global Compact, 2006). The global reporting initiative (GRI) is a leading organization in the sustainability field. GRI promotes the use of sustainability reporting as a way for organizations to become more sustainable and contribute to sustainable development. GRI has pioneered and developed a comprehensive sustainability reporting framework, which is widely used around the world. A sustainability report is a report published by a company or organization about the economic, environmental, and social impacts caused by its everyday activities (GRI, 2006). ISO 26000:2010 provides guidance rather than requirements, so it cannot be certified, unlike some other well-known ISO standards. Instead, it helps clarify what social responsibility is, helps businesses and organizations translate principles into

Table 2. CSR Guidelines and Standards

\begin{tabular}{|c|c|c|c|c|}
\hline European Commission (2001) & UN Global Compact & GRI & ISO26000 & Core subjects of CSR \\
\hline $\begin{array}{l}\text { Social responsibility integrated } \\
\text { management }\end{array}$ & & & $\begin{array}{l}\text { Organizational } \\
\text { governance }\end{array}$ & 1. Leadership \\
\hline Adaptation to change & \multicolumn{3}{|c|}{ Economic } & 2. Employee \\
\hline Human rights & Human rights & Human rights & Human rights & 3. Environment \\
\hline $\begin{array}{c}\text { Human resource management/ } \\
\text { Health and safety at work }\end{array}$ & Labour & $\begin{array}{l}\text { Labor practices and } \\
\text { decent work }\end{array}$ & Labour practices & 4. Society \\
\hline \multirow[t]{2}{*}{$\begin{array}{l}\text { Management of environmental } \\
\text { impacts and natural resources/ Global } \\
\text { environment concerns }\end{array}$} & Environment & Environmental & Environment & 5. Product and service \\
\hline & Anti-corruption & & Fair operating practices & \\
\hline Local communities & & Society & $\begin{array}{l}\text { Community involvement } \\
\text { and development }\end{array}$ & \\
\hline $\begin{array}{l}\text { Business partners, suppliers and } \\
\text { consumers }\end{array}$ & & Product responsibility & Consumer issues & \\
\hline \multicolumn{5}{|l|}{ Social and eco- labels } \\
\hline \multicolumn{5}{|l|}{ SRI (Socially responsible investment) } \\
\hline \multicolumn{5}{|l|}{ Quality in work } \\
\hline $\begin{array}{l}\text { Social responsibility reporting } \\
\text { and auditing }\end{array}$ & & & & \\
\hline
\end{tabular}


effective actions, and shares best practices relating to social responsibility globally. It is aimed at all types of organizations, regardless of their activity, size, or location (Mulej et al., 2012). The standard was launched in 2010 following five years of negotiations between many different stakeholders across the world. Representatives from government, NGOs, industry, consumer groups, and labour organizations around the world were involved in its development (ISO, 2010).

We collected the guidelines and standards related to CSR into a table to provide an overall picture about the approach and demonstrate the core subjects they have in common. As a result, the determined elements of the CSR concept can be found in the last column of the table.

After collecting the content, the next step was to find a framework that is appropriate to develop the CSR excellence model. The two most popular excellence models are the Malcolm Baldrige National Quality Award (MBNQA), which recognizes US organizations in the business, health care, education, and nonprofit sectors for performance excellence (NIST, 2014). The other one is the EFQM excellence model, which was introduced in 1992. It is based on a set of European values and served as a powerful tool for integrating quality in organizations (EFQM, 2017).

We have chosen the European model, which is closer to that of Hungarian business culture. Today, it is the most widely used business excellence model in Europe; more than 30,000 organizations use it to improve performance. The model is a practical, nonprescriptive framework that enables organisations to assess where they are on the path to excellence and provides a basic structure for the organisation's management system (Neergaard-Pedersen, 2012). Kumar and Balakrishnan have identified how the EFQM excellence model explains the concept of putting CSR into practice to support social responsibility and sustainability (Kumar-Balakrishnan, 2011). Other researchers such as Neergaard, Pedersen, Avlonas, Jankal, and Jankalova also examined the relationship between CSR and the excellence models (Avlonas, 2004; Neergaard-Pedersen, 2012;
Jankal-Jankalova, 2016). Their research focuses on the implementation of CSR with the help of the excellence models as well as to analyse various approaches for the evaluation of CSR. These researches present the CSR elements in the excellence models, while we collected all the CSR elements from the guidelines and standards and developed a model based on the framework of the EFQM excellence model. The EFQM excellence model contains three integrated components: the fundamental concepts of excellence; the EFQM excellence model; and the RADAR logic. The fundamental concepts of excellence are the underlying principles that are the essential foundation of achieving sustainable excellence for any organisation. The EFQM excellence model is a framework to help organisations convert the fundamental concepts and RADAR logic into practice. Radar logic is a dynamic assessment framework and management tool that provides a structured approach to question the performance of an organisation. It also supports the scoring mechanism behind the assessment schemes and can help to lead change and manage improvement projects in an organisation (EFQM, 2017).

The EFQM excellence model is a framework based on nine criteria. Five of these are "enablers" and four are "results." The enabler criteria cover what an organisation does and how it does it. The results criteria cover what an organisation achieves. Results are caused by enablers, and enablers are improved using feedback from results. Each criterion is supported by a number of criterion parts. Criterion parts are statements that describe in further examples what should be considered in the course of an assessment.

\section{Results and Discussion}

The areas of the CSR excellence model were determined on the basis of the international standards and guidelines. The certain areas of the model also are divided into criterion parts on the basis of the sub-areas of international standards and guidelines, and the collected content elements of 250

Table 3. CSR Excellence Model

\begin{tabular}{|c|c|c|c|c|}
\hline Enablers & & & Results & \\
\hline \multirow{3}{*}{$\begin{array}{l}\text { 1. Responsible } \\
\text { leadership }\end{array}$} & 2. Employee & \multirow{3}{*}{$\begin{array}{l}\text { 5. Products \& } \\
\text { Services }\end{array}$} & 6. Employee results & \multirow{3}{*}{$\begin{array}{l}\text { 9. CSR } \\
\text { Results }\end{array}$} \\
\hline & 3. Strategy & & 7. Customer results & \\
\hline & 4. Society \& Environment & & 8. Society \& Environment results & \\
\hline
\end{tabular}


European CSR reports. The assessment tool is intended to evaluate the CSR activities of organisations of all sizes and from all sectors in order to be able to compare them. It was therefore important to collect all the elements of CSR from the reports and standards that are used in practice. Beyond the assessment, the aim of the CSR EMAT system is to provide guidance for company managers in the interpretation of the CSR approach and a type of best practice database that can help them to learn about the opportunities of applying this concept. The fundamental concepts of the CSR excellence management and assessment tool (CSR EMAT) are 1) responsible and ethical management; 2) strategy for responsible and sustainable operation and development; 3) creating value for the society; 4) taking into account the interests of stakeholders; 5) employee appreciation and motivation; 6) relations with partners and customers; 7) responsible product and service; 8) responsibility for the environment. The CSR EMAT is a complex management guidance that, besides the fundamental concepts and their definitions, also contains the assessment tool, which can evaluate the intensity of the CSR activity of a certain company.

The validation process was carried out at the partner companies of the University of Pannonia. Thirty structured interviews were made with managers in various fields where they checked the content of the assessment tool and carried out the company's self-assessment as well. Following the validation, 90 more companies (small, medium, and large companies) in Budapest (49\%) and in the country (51\%) carried out their self-assessment with the help of CSR EMAT. Based on the opinion of business leaders, they were able to successfully apply CSR EMAT and identify the areas for improvement after the assessment. The results have been continuously recorded in a database.

Table 4 shows the summary table of the company's CSR excellence at the end of the assessment tool. Each company has this table and a graphic illustration of its results following the completion of the evaluation system. The assessment tool consists of statements concerning the nine areas (enablers and results) of the CSR excellence model. The results show the percentage that the analysed company received out of $100 \%$ in the listed areas. In addition to the summary table and the graphic illustration, the company also received a text summary on the basis of the results. Conclusions can help the companies to pinpoint the development directions.

Table 5 shows the best results of the evaluated companies.

The results show a mixed picture; in the sample, there are small, medium, and large companies with different areas of activity and ownership structures. It was important to examine all these aspects. As we stated, the CSR EMAT is applicable for small, medium, and large companies regardless of their profile. We assumed that the foreign-owned large companies will be the most excellent in CSR activity, as they are more familiar with the approach. We also assumed that the CSR intensity is higher in case of companies in Budapest (the Hungarian capital city) than in rural businesses. Micro businesses are not included in the sample because, in their case, the management-level application cannot be interpreted. For Table 5, we collected the best 10 evaluated companies. The results

Table 4. Summary Table of the Company's CSR Excellence

\begin{tabular}{|c|c|c|c|c|c|c|}
\hline \multicolumn{7}{|l|}{ Result of the Company's CSR Excellence } \\
\hline Record the Number of Ticks Scored & $\mathrm{E}$ & $\mathrm{D}$ & $\mathrm{C}$ & $\mathrm{B}$ & A & $\%$ Achievement \\
\hline Responsible leadership & 0 & 0 & 1 & 2 & 2 & 80 \\
\hline Employee & 0 & 0 & 0 & 0 & 6 & 100 \\
\hline Strategy & 0 & 0 & 0 & 2 & 2 & 87.5 \\
\hline Society \& Environment & 0 & 0 & 1 & 2 & 2 & 80 \\
\hline Products \& Services & 0 & 0 & 0 & 0 & 5 & 100 \\
\hline Employee results & 0 & 0 & 1 & 1 & 5 & 89.3 \\
\hline Customer results & 1 & 0 & 0 & 1 & 3 & 75 \\
\hline Society \& Environment results & 0 & 1 & 0 & 0 & 4 & 85 \\
\hline CSR results & 1 & 0 & 1 & 2 & 1 & 60 \\
\hline Total number of ticks (a) & 2 & 1 & 4 & 10 & 30 & 47 \\
\hline Factor (b) & 0 & 25 & 50 & 75 & 100 & \\
\hline Value $(\mathrm{a} \times \mathrm{b})$ & 0 & 25 & 200 & 750 & 3000 & 3975 \\
\hline
\end{tabular}

Total/47 $=84.6 \%$ CSR excellence

Source: Author's illustration 
Table 5. Best results of the evaluated companies with CSR EMAT

\begin{tabular}{|c|c|c|c|c|c|c|c|c|c|c|c|c|c|c|}
\hline 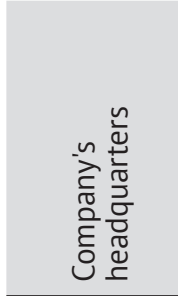 & 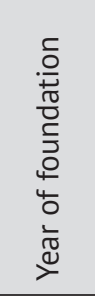 & 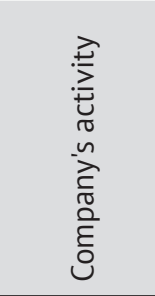 & 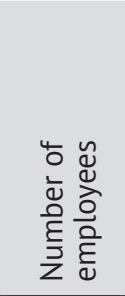 & 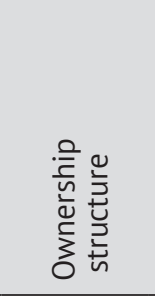 & 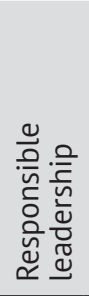 & 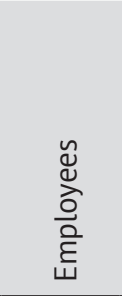 & 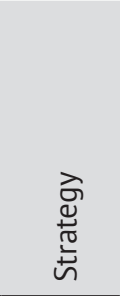 & 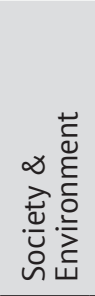 & 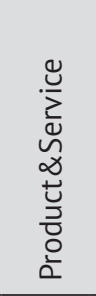 & 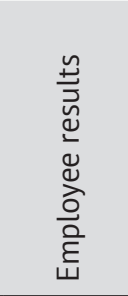 & 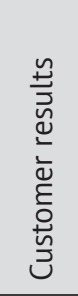 & 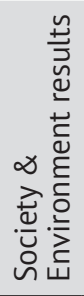 & 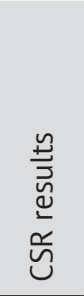 & 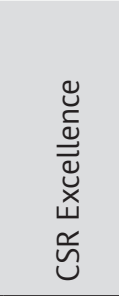 \\
\hline w. & 995 & dustrial & + & & $\%$ & & $\%$ & $100 \%$ & & $8 \%$ & $55 \%$ & $55 \%$ & $50 \%$ & $73,94 \%$ \\
\hline Countryside & 396 & & 2200 & foreign & $\%$ & 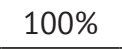 & $\%$ & $95 \%$ & $\%$ & $\%$ & $40 \%$ & $45 \%$ & $35 \%$ & 7 \\
\hline udapest & 03 & rvico & 1 & for & $90 \%$ & $95,80 \%$ & $93,75 \%$ & $90 \%$ & $100 \%$ & $6 \%$ & $90 \%$ & $85 \%$ & $30 \%$ & $79,80 \%$ \\
\hline (3) & 35 & ervice & + & 1010 & $80 \%$ & $\%$ & $87,50 \%$ & $80 \%$ & $100 \%$ & $\%$ & $75 \%$ & $85 \%$ & $60 \%$ & $84,60 \%$ \\
\hline Countrucido & 07 & dustrind & 75 & for & $00 \%$ & $\%$ & 93 & $85 \%$ & 10 & $\%$ & $\%$ & $65 \%$ & $20 \%$ & $71,80 \%$ \\
\hline udapest & 95 & vice & 20.000 & foreign & $60 \%$ & $62,50 \%$ & $75 \%$ & $90 \%$ & $75 \%$ & $60 \%$ & $90 \%$ & $85 \%$ & $75 \%$ & $74,40 \%$ \\
\hline$x^{2}+2+3$ & 12 & industrial & 2700 & foreign & $\%$ & $\%$ & 8 & $90 \%$ & 6 & $\%$ & $70 \%$ & 70 & $80 \%$ & $71,81 \%$ \\
\hline Idapest & 99 & Jerice & 1600 & foreign & $75 \%$ & $91,60 \%$ & $81,25 \%$ & $85 \%$ & $95 \%$ & $\%$ & $90 \%$ & $70 \%$ & $75 \%$ & $76,59 \%$ \\
\hline Iae & 02 & ce & 110 & 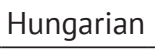 & $100 \%$ & $100 \%$ & $100 \%$ & $100 \%$ & $100 \%$ & $53,57 \%$ & $75 \%$ & $85 \%$ & $60 \%$ & $84,57 \%$ \\
\hline ountryside & 1996 & service & 180 & Hungarian & $85 \%$ & $100 \%$ & $81,25 \%$ & $85 \%$ & $90 \%$ & $46,43 \%$ & $30 \%$ & $75 \%$ & $45 \%$ & $70,21 \%$ \\
\hline
\end{tabular}

Source: Author's illustration

Table 6. Worst Results of the Evaluated Companies with CSR EMAT

\begin{tabular}{|c|c|c|c|c|c|c|c|c|c|c|c|c|c|c|}
\hline 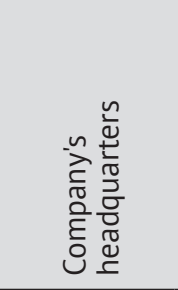 & 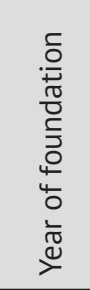 & 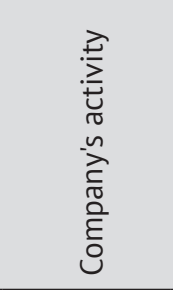 & 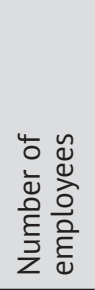 & 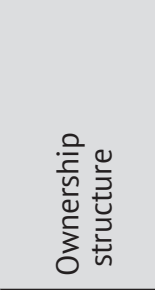 & 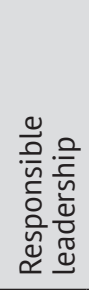 & 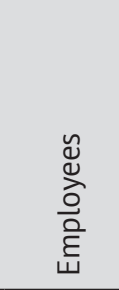 & 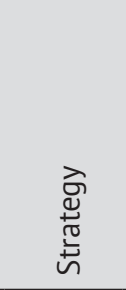 & 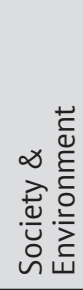 & 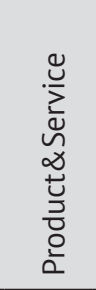 & 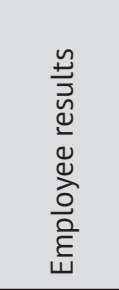 & 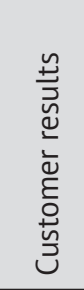 & 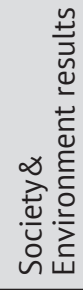 & 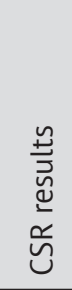 & 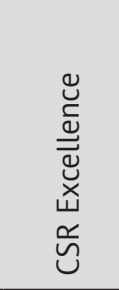 \\
\hline Cour & 00 & du & 650 & foreign & $\%$ & $\%$ & 1 & $70 \%$ & $\%$ & $\%$ & $\%$ & $5 \%$ & $0 \%$ & $\%$ \\
\hline Countryside & 004 & industrial & 249 & Hung & $40 \%$ & $87,50 \%$ & $625 \%$ & $95 \%$ & $90 \%$ & $21,43 \%$ & $50 \%$ & $30 \%$ & $30 \%$ & $52,66 \%$ \\
\hline Countryside & 1993 & $\begin{array}{l}\text { ind } \\
\text { and }\end{array}$ & 38 & an & $90 \%$ & $79,20 \%$ & $12,50 \%$ & $90 \%$ & $65 \%$ & $32,10 \%$ & $45 \%$ & $45 \%$ & $10 \%$ & $53,72 \%$ \\
\hline Coun & 2001 & $\begin{array}{l}\text { industrial } \\
\text { and service }\end{array}$ & 17 & ian & $70 \%$ & $58,30 \%$ & $12,50 \%$ & $85 \%$ & $70 \%$ & $5,70 \%$ & $35 \%$ & $35 \%$ & $5 \%$ & $47,34 \%$ \\
\hline Countryside & 1939 & industrial & 330 & 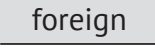 & $25 \%$ & $50 \%$ & $31,25 \%$ & $35 \%$ & $80 \%$ & $32,14 \%$ & $50 \%$ & $65 \%$ & $25 \%$ & $43,62 \%$ \\
\hline Coun & 001 & 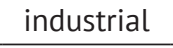 & 130 & 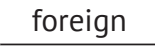 & $65 \%$ & 83 & 6 & $30 \%$ & $95 \%$ & $\%$ & $40 \%$ & $10 \%$ & $0 \%$ & $45,75 \%$ \\
\hline Budapest & 2008 & service & 53 & Hungarian & $55 \%$ & $66,67 \%$ & $43,75 \%$ & $60 \%$ & $65 \%$ & $28,57 \%$ & $40 \%$ & $55 \%$ & $30 \%$ & $47,34 \%$ \\
\hline Coun & 1996 & inturstriat & 535 & 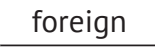 & $45 \%$ & $95,80 \%$ & $37,50 \%$ & $65 \%$ & $100 \%$ & $42,86 \%$ & $45 \%$ & $40 \%$ & $5 \%$ & $53,72 \%$ \\
\hline Countryside & 1989 & industrial & 65 & Hungarian & $75 \%$ & $87,50 \%$ & $37,50 \%$ & $90 \%$ & $80 \%$ & $25 \%$ & $20 \%$ & $45 \%$ & $15 \%$ & $52,66 \%$ \\
\hline Countryside & 2004 & service & 120 & Hungarian & $35 \%$ & $70,83 \%$ & $18,75 \%$ & $65 \%$ & $70 \%$ & $42,86 \%$ & $60 \%$ & $45 \%$ & $10 \%$ & $47,34 \%$ \\
\hline
\end{tabular}

Source: Author's illustration

show that the companies can be found both in Budapest and the countryside, and all sizes are represented. Nevertheless it can be stated that the most CSR excellent companies are from the service sector with foreign ownership. The results also show that those companies are the most excellent in CSR whose strategy includes commitment to social responsibility.
It is important to have the CSR goals in a written form and to inform the stakeholders about it as well. Most of the companies in this table prepare CSR reports regularly.

Contrary to the Table 5, Table 6 shows the worst results of the evaluated companies. The results show that most of the 
least-excellent companies are located in the countryside, and they are mainly from the industrial sector. It is proven that the application of the CSR approach depends on the leadership. The results from Table 6 confirm this statement, as the area of responsible leadership and strategy received a small percentage. It means that the leadership is not committed to CSR, and they do not have this approach in their strategy. The poor results (employee results) also show that they do not even provide more to their employees than is required.

\section{Conclusions}

Summing up the results of the research, it can be stated that both hypothesis are confirmed, as the EFQM excellence model is an appropriate framework for developing a CSR excellence model. The CSR EMAT can help managers to identify the CSR activities of their companies; it also shows improvement opportunities, as the model is based on the logic of TQM (total quality management). With the use of the assessment tool, the CSR intensity of different companies (in size, profile, and ownership structure) can be comparable. Our primary goal was to develop a management tool for the Hungarian company executives that can help them in responsible and sustainable operation. The leaders of the evaluated companies confirmed that they have successfully applied the CSR EMAT. The evaluation revealed that the most CSR excellent companies are from the service sector and have foreign owners. The results also show that the strategy of the most excellent companies includes commitment to social responsibility. Conversely, in the case of the least excellent companies, the leadership is not committed toward CSR, and they do not have this approach in their strategy. Most of these companies are located in the countryside, and they are mainly from the industrial sector. These results once again confirm the fact that the leadership needs to understand the CSR approach because responsible operation depends mainly on their commitment. The results of the evaluated companies are collected into a database providing an opportunity for further research, correlation studies, cluster analysis, and formulation of general statements.

CSR EMAT is available also in English; therefore, company executives from other countries can use it as well. As a further research, together with IT experts, we plan to develop an online platform for CSR EMAT and evaluate different companies in other countries as well and compare the results to see whether there is a correlation between CSR intensity and national culture.

\section{References}

Adelina, M., Broadbridge, G. A., Maxwell, S., \& Ogden, M. (2007). Experiences, perceptions and expectations of retail employment for Generation Y. Career Development International, 12(6), 523-544. https://doi.org/10.1108/13620430710822001

Avlonas, N. (2004). The EFQM framework for corporate social responsibility. Retrieved from: http://www.das-nachhaltige-krankenhaus.at/ Dokumente/docs/EFQMCSRFrameworkECOPF.pdf

Benn, S., \& Bolton, D. (2011). Key concepts in corporate social responsibility. London: SAGE Publications.

Berkes, N., Birkner, Z., \& Ernszt, I. (2015). Sustainable and responsible operation in tourism. In: Útkeresés - Tudomány - Felelősség (eds) Svéhlik Csaba, Kheops Autómobil Kutató Intézet, Mór, 2015.

Birkner, Z., \& Máhr, T. (2016). Interpreting innovation - in another way. Budapest Management Review, 47(10), 39-50.

Blowfield, M., \& Murray, A. (2008). Corporate responsibility- a critical introduction. Oxford: Oxford University Press.

Boutilier, R. (2009). Stakeholder politics: Social capital, sustainable development and the corporation. Stanford: Stanford University Press.

Bowen, H. R. (1953). Social responsibility of the businessman. New York: Harper \& Row.

Braun, R. (2013). A vállalatok politikája: vállalati társadalmi felelösségvállalás, vállalati közösségek és a vállalati stratégia jövője. Vezetéstudomány, 44, Január, 18-28.

Braun, R., \& Line, M. (2007). Baseline study on CSR practices in the new EU member states and candidate countries. Retrieved from http:// docs.china-europa-forum.net/undpconference_26062007_brochure.pdf.

Broomhill, R. (2007). Corporate Social Responsibility: Key Issues and Debates. Dunstan Papers. Adelaide: University of Adelaide.

Brundtland, H. (1987). Report of the World Commission on Environment and Development: Our Common Future. Retrieved from http://www. un-documents.net/our-common-future.pdf.

Crowther, D., \& Martinez, E. O. (2004). Corporate social responsibility: History and principles. Retrieved from http://www.davideacrowther. com/csrmodule/csrreading3b.pdf

Dahlsrud, A. (2008). How Corporate Social Responsibility is defined: An analysis of 37 definitions. Corporate Social Responsibility and Environmental Management 15 (1), 1-13. https://doi.org/10.1002/csr.132

EFQM (2017). An Overview of the EFQM Excellence Model. Retrieved from http://www.efqm.org/sites/default/files/overview_ efqm_2013_v2_new_logo.pdf 
European Commission (2002). Communication from the commission concerning corporate social responsibility: A business contribution to sustainable development. COM (2002) 347 final. Brussels: European Commission.

European Commission (2005). Opinion of the European Economic and Social Committee on Information and measurement instruments for corporate social responsibility (CSR) in a globalised economy. Retrieved from http://eur-lex.europa.eu/legal-content/EN/TXT/?uri=CELEX\%3A52005IE0692.

Fekete, L. (2005). Social Welfare Lagging Behind Economic Growth. In: Habish, A. - Jonker, J. - Wegner, M. - Schmidpeter, R. (Eds), Corporate Social Responsibility Across Europe. Springer: Berlin-Heidelberg, 141-150.

Frank, R. H. (2004). What price the moral high ground? Ethical dilemmas in competitive environments. Princeton: Princeton University Press. GRI (2006). Global Report Initiative. Sustainability Reporting Standards. Retrieved from www.globalreporting.org.

Harrison, J. S., \& Wicks, A. C. (2013). Stakeholder theory, value, and firm performance. Business Ethics Quarterly, 23 97-124. https://doi. org/10.5840/beq20132314

Hatch, N. W., \& J. H. Dyer (2004). Human capital and learning as a source of sustainable competitive advantage. Strategic Management Journal, 25 (1), 1155-1178. https://doi.org/10.1002/smj.421

Holliday, C. O., Schmidheiny, S., \& Watts, P. (2002). Walking the talk - the business case for sustainable development. San Francisco: Greenleaf Publishing, Berrett-Koehler Publishers.

Idowu, S. O. (2013). Encyclopedia of corporate social responsibility. New York: Springer. https://doi.org/10.1007/978-3-642-28036-8

Idowu, S. O., \& Filho W. L., (2009). Professionals' perspectives of corporate social responsibility. New York: Springer.

International Federation for Human Rights (2006). An Overview of corporate social responsibility in Hungary. Budapest: FIDH.

IISD, International Institute for Sustainable Development (2004). ISO Social Responsibility Standardization. An outline of the issues. Retrieved from https://www.iisd.org.

ISO (2010). International Standards Organization 2010. ISO 26000:2010. Retrieved from http://www.iso.org/iso/social_responsibility.

Jankal, R., \& Jankalova, M. (2016). The application of the EFQM excellence model by the evaluation of corporate social responsibility activities of companies. Procedia Economics and Finance 39, 660-667. https://doi.org/10.1016/S2212-5671(16)30313-6

Kaszás, N., Péter, E., Keller, K., \& Kovács, T. (2016). Boundless opportunities with definite limitations. Deturope, 8(1), 5-20.

Kun, A. (2004). The basic lines of the thematization of corporate social commitment in the European Union. (A vállalati szociális elkötelezettség tematizálásának alapvonalai az Európai Unióban.) Jogelméleti szemle. Retrived from http://www.jogiforum.hu/ folyoiratok/11/68

Kumar, D.A., \& Balakrishnan, V. (2011). Corporate social responsibility: Existing practices vs CSR framework. Global Journal of Management and Business Research, 11(9), 50-56.

Laasch, O., \& Conaway, R. N. (2013). Responsible business: Managing for sustainability, ethics and citizenship. Monterrey: Editorial Digital ITESM.

Laasch, O., \& Conaway, R. N. (2015). Principal of responsible management: Glocal sustainability, responsibility and ethics. Stamford: Cengage Learning.

Lacey, P., Cooper, T., Hayward, R., \& Neuberger, L. (2010). A new era of sustainability: UN global compact-Accenture CEO study 2010. Retrieved from http://web2.fit.edu/sustainability/documents/UNGC\%20\&\%20Accenture.\%202010.\%20CE0\%20study.pdf

Laszlo C. (2008). Sustainable value: How the world's leading companies are doing well by doing good. Stanford: Stanford University Press.

Lepoutre, J., \& Heene, A. (2006). Investigating the impact of firm size on small business social responsibility: A critical review. Journal of Business Ethics, 67, 257-273. https://doi.org/10.1007/s10551-006-9183-5

Maak T., \& Pless, N. M. (2006). Responsible leadership in a stakeholder society: A relational perspective. Journal of Business Ethics, 66, 99-115. https://doi.org/10.1007/s10551-006-9047-z

Matten, D., \& Moon, J. (2004). A conceptual framework for understanding CSR. Corporate social responsibility across Europe. Berlin-Heidelberg: Springer.

Matten, D., \& Moon, J. (2008). "Implicit” and "Explicit" CSR: a conceptual framework for a comparative understanding of corporate social responsibility. Acad. Management. Rev. 33(2), 404-424. https://doi.org/10.5465/AMR.2008.31193458

Mulej, M., \& Dyck, R. (2013). Social responsibility beyond neoliberalism and charity. Oak Park: Bentham Science Publishers.

Neergaard P., \& Pedersen, E. R. (2012). The Business Excellence Model for CSR Implementation? Nang Yan Business Journal. Centre for Corporate Social Responsibility. Denmark: Copenhagen Business School.

Németh, K., \& Péter, E. (2016). Szemléletformáló tevékenységek az energia-és környezettudatosság területén.XX. Apáczai Napok Nemzetközi Tudományos Konferencia. Győr, Magyarország.

NIST (2014). Malcolm Baldrige National Quality Award criteria. Gaithersburg, MD: US Department of Commerce, National Institute of Science and Technology. Retrieved from http://www.nist.gov/baldrige.

OECD (2004). Principles of corporate governance. Paris: OECD.

Segal, J-P.- Sobczak, A.- Triomphet C-A. (2003). Corporate social responsibility and working condition. Dublin: European Foundation for the Improvement of Living and Working Conditions.

Szlávik, J. (2009). Corporate social responsibility. (In Hungarian: A vállalatok társadalmi felelősségvállalása.). Budapest: Complex Kiadó $\mathrm{Kft}$.

Tari, A. (2011). Z generáció. (Generation Z). Budapest: Tercium Könyvkiadó. 
Templar, R. (2005). The rules of management. A definitive guide to managerial success. Upper Sadle River, New Jersey: Pearson Education Limited.

UN Global Compact (2006). The Foundation for the Global Compact. Retrieved from http://globalcompactfoundation.org.

Venturelli A. Caputo, F. Leopizzi R., Giovanni M., \& Chiara M. (2017). How can CSR identity be evaluated? A pilot study using a fuzzy expert system. Journal of Cleaner Production, 141, 1000-1010. https://doi.org/10.1016/j.jclepro.2016.09.172

Vogel, D. (2006). The market for virtue: The potential and limits of corporate social responsibility. Washington, D. C.: Brookings Institution Press.

Waddock, S., \& Bodwell, C. (2007). Total responsibility management: The manual. Sheffield, UK: Greenleaf.

WBCSD (2000). Corporate social responsibility (CSR). Retrieved from http://www.wbcsd.org/.

\section{Author}

Nora Rodek Berkes is a lecturer at University of Pannonia Nagykanizsa Campus. She is a PhD candidate in management and business administration at the Doctoral School of University of Pannonia. Her research topics are CSR (corporate social responsibility), sustainable and responsible management, social innovation. Beside the theoretical research of CSR, she is active also in practice, as she participates in many projects and programs with the topic of social responsibility. The author can be contacted at rodek.nora@uni-pen.hu.

\section{'Orodje za upravljanje in ocenjevanje odličnosti družbene odgovornosti podjetij' EMAT je priložnost za odgovorno odločanje}

\section{Izvleček}

Družbena odgovornost podjetij je pričakovano ravnanje v zahodnih državah, vendar še vedno nima jasne opredelitve na Madžarskem. Zaradi vse večjega ugleda družbeno odgovornega pristopa podjetij se pričakujeta tudi družbeno odgovorno razmišljanje in delovanje podjetij, ki delujejo na Madžarskem. Vodstva podjetij v številnih primerih izvajajo dejavnosti družbene odgovornosti podjetij, vendar se tega niti ne zavedajo. Zato je bil cilj te raziskave razvoj smernic in ocenjevalnih kriterijev, ki lahko pomagajo menedžerjem pri odgovornem odločanju in uporabi družbeno odgovornega pristopa podjetij na strateški ravni. Po drugi strani pa to menedžersko orodje omogoča merjenje odličnosti družbene odgovornosti podjetij in primerjavo njihove uspešnosti, kar ponuja priložnosti za nadaljnje raziskave. Študija predstavlja razvoj orodja za upravljanje in ocenjevanje odličnosti družbene odgovornosti podjetij in rezultate, dosežene z meritvami.

Ključne besede: družbena odgovornost podjetij, model odličnosti EFQM, 'orodje za upravljanje in ocenjevanje odličnosti družbene odgovornosti podjetij' EMAT 